\title{
Prenatal Diagnosis of Type II Glycogenosis (Pompe's Disease) Using Microchemical Analyses
}

\author{
M. F. NIERMEIJER, (54) J. F. KOSTER, M. JAHODOVA, J. FERNANDES, M. J. HEUKELS-DULLY, AND \\ H. GALJAARD \\ Department of Cell Biology and Genetics, Department of Biochemistry, Department of Obstetrics and Gynecology, \\ and Department of Pediatrics, Medical Faculty, Erasmus University, Rotterdam, The Netherlands
}

\section{Extract}

The number of cultured amniotic fluid cells required for the prenatal diagnosis of metabolic defects can be reduced by using microchemical techniques. Six cases are presented of prenatal monitoring for glycogenosis type II (Pompe's disease), in which $\alpha$-glucosidase assays were performed in (sub)microliter volumes with 4-methylumbelliferyl- $\alpha$-D-glucopyranoside as a substrate. Using cell homogenates, the period of time between amniocentesis (performed in the 14th-15th week of pregnancy) and the diagnosis varied from 12-22 days. This could further be reduced to about 10 days when microchemical enzyme analyses were performed on dissected groups of small numbers $(100-300)$ of freeze-dried cultured cells. The $\alpha$-glucosidase activities (expressed per cell) obtained by these microtechniques were found to be in good agreement with data from conventional biochemical assays. Furthermore, it was observed that the acid $\alpha$-glucosidase activity is much lower in primary cultures of amniotic fluid cells, approximately $100-200 \mathrm{pmol} / \mathrm{min} / \mathrm{mg}$ protein than in cells from later subcultures, which had activities up to $700-1,600 \mathrm{pmol} / \mathrm{min} / \mathrm{mg}$ 2-3 weeks after the last subcultivation. Primary cultures of normal amniotic fluid cells should therefore be used as a control in prenatal diagnosis; this is especially important when microtechniques are used to enable an early prenatal diagnosis.

\section{Speculation}

In prenatal diagnosis of at least seven lysosomal storage diseases the time interval between amniocentesis and the diagnosis can be reduced by using microchemical assays on dissected groups of 100-300 freeze-dried cultured amniotic fluid cells. Correct interpretation of the analytical data requires the use of primary cultures of normal amniotic fluid cells as controls. If enzymatic activities in various strains of fibroblasts and amniotic fluid cells are to be compared, cell cultivation conditions should be strictly controlled.

The presence of lysosomal $\alpha$-1,4-glucosidase activity in leucocytes (18) has facilitated the diagnosis of glycogenosis type II (Pompe's disease). The finding that acid $\alpha$-1,4-glucosidase activity was also deficient in cultured skin fibroblasts from patients with Pompe's disease (34) suggested the possibility of prenatal detection $(6,30,31)$. When parents at risk for an affected child ask for prenatal monitoring the time interval between amniocentesis and the diagnosis should be kept as short as possible. Unfortunately, a direct assay of enzymatic activities in uncultured amniotic fluid cells or in amniotic fluid supernatant is unreliable $(6,30)$. However, when cultured amniotic fluid cells were used for biochemical analysis, 4-6 weeks were required to obtain sufficient cell material $(6,24,30,31)$ and even longer periods $(2,10)$ have been described for other metabolic diseases.

The number of cells required and the time needed for the diagnosis can be reduced if microchemical techniques are used. These methods were originally developed for histochemical studies on tissue sections $(16,25-28)$ and have been adapted for the analysis of small numbers of cultured amniotic fluid cells $(12,13)$. The first examples of their application for prenatal diagnosis have been reported $(11,14)$.

The present paper describes six prenatal analyses for Pompe's disease using microchemical techniques. Some problems in the interpretation of the analytical data are discussed in relation to the clinical and biochemical diagnosis of affected siblings, the use of proper control material, and the influence of cell culture conditions on enzymatic activity.

\section{MATERIAL AND METHODS}

Acid and neutral $\alpha-1,4$-glucosidase assays on tissues and leucocytes of affected patients and heterozygous carriers were performed as described previously (21). In pregnancies at risk for Pompe's disease $10-20 \mathrm{ml}$ of amniotic fluid was obtained by transabdominal amniocentesis in the 14-16th week of pregnancy (calculated from the last menstrual period) after ultrasound localization of the placenta.

\section{PREPARATION OF CELL MATERIAL}

The amniotic fluid sample is centrifuged in siliconized glass tubes for $5 \mathrm{~min}$ at $80 \times g$ and the supernatant is centrifuged for another $10 \mathrm{~min}$ at $1,500 \times \mathrm{g}$ and stored at $-70^{\circ}$ until analysis. The cell pellet is resuspended in Ham's F-10 medium (44) supplemented with $20 \%$ fetal calf serum (45), penicillin $(100 \mathrm{U} / \mathrm{ml})$, and streptomycin $(50 \mu \mathrm{g} / \mathrm{ml})$. Cell cultivation is carried out in a fully humidified atmosphere with $5 \% \mathrm{CO}_{2}$ in air. For microbiochemical analyses on cell homogenates cell cultivation is performed in 35 mm plastic Petri dishes (46) and cell counting and homogenization is carried out as described earlier (13). When microchemical assays are to be performed on dissected groups of freeze-dried cells an aliquot of the cell suspension is cultured on a Mylar dish consisting of a glass ring of $5 \mathrm{~cm}$ outside diameter with a bottom of thin plastic film (47). When sufficient cell growth has occurred, the dish is quickly frozen and freeze-dried overnight at $-45^{\circ}$ in vacuo. Subsequently a measured number of cells (100-300) are dissected under a stereomicroscope as described earlier (13). In each prenatal diagnosis confluent subcultures of amniotic fluid cells from a normal pregnancy (14-17th week), fibroblasts from a previous affected sibling, or a nonrelated patient with Pompe's disease, and fibroblasts from the heterozygous parents and from normal individuals were used as controls. Cells were grown in Ham's F-10 medium supplemented with $15 \%$ fetal calf serum and 
antibiotics. In one case ( $V$ Co 2$)$ a primary culture of normal amniotic fluid cells was used as a control (48).

\section{MICROCHEMICAL ANALYSIS}

Either $0.3-1 \mu \mathrm{l}$ cell homogenate or dissected pieces of plastic film containing a small number of lyophilized cells were incubated under microscopic control in small volumes $(0.6-2 \mu 1)$ of substrate covered by paraffin oil, using the "oil well technique" (28).

Incubation in $2.2 \mathrm{mM}$ 4-methylumbelliferyl- $\alpha$-D-glucopyranoside (49) in $0.2 \mathrm{M}$ acetate buffer at pH 4.0 was carried out for 1-2 $\mathrm{hr}$ at $37^{\circ}$. The reaction mixture was then diluted with $500 \mu 10.5 \mathrm{M}$ carbonate buffer (pH 10.7) and the fluorescence was read in a fluorometer (50) (excitation $365 \mathrm{~nm}$; emission $448 \mathrm{~nm}$ ). The enzymatic activity was expressed per cell when dissected groups of freeze-dried cells were analyzed. In the analysis of cell homogenates the protein content was determined according to the method of Lowry (27) in a final volume of $60 \mu \mathrm{l}$. The enzymatic activity was expressed as moles of methylumbelliferone liberated per minute per milligram of protein. For comparative studies with the assays on dissected groups of cells, the analytical data on cell homogenates were also expressed per cell as calculated from the cell counts after trypsinization. The enzymatic analyses of amniotic fluid supernatant for acid and neutral $\alpha$-1,4-glucosidase were performed as described previously (21) and expressed per milligram of protein. Neutral $\alpha$-glucosidase assays were performed as a reference enzyme; assay conditions were the same as for acid glucosidase except that incubation was carried out in $0.1 \mathrm{M}$ fumarate buffer at $\mathrm{pH} 6.5$.

\section{RESULTS}

\section{PRENATAL DIAGNOSIS USING MICROCHEMICAL ANALYSIS OF CELL HOMOGENATES}

Family $1 B i$ had one healthy boy and two children who died at 6 and 5 months of cardiopulmonary failure; in the youngest child ( 1 $B i$ 3) Pompe's disease was diagnosed by the demonstration of a deficient acid $\alpha$-1,4-glucosidase activity in leucocytes and muscle (Table 1). In the fourth pregnancy amniocentesis had to be repeated because of insufficient amniotic fluid cell growth. The results of enzyme assays on cultured cells from the second sample (obtained in the 19th week) are given in Table 2 ( 1 Bi 4). The $\alpha$-glucosidase activity was found to be about $1 \%$ of the value in control fibroblasts, and it was less than $10 \%$ of the values found in fibroblast cultures from the heterozygous parents. Assays on neutral glucosidase as a reference showed activities in the control range. The parents were informed of the presence of an affected fetus and they requested interruption of the pregnancy. Analyses on fetal tissues after induced abortion with hypertonic saline solution showed a deficiency of acid glucosidase activity (Table 3) which confirmed the prenatal diagnosis of Pompe's disease.

In family II No the first child $(I I N O I)$ died at the age of 2 months with symptoms of generalized muscle hypotonia, cardi- orespiratory insufficiency, and hepatosplenomegaly. A deficient acid $\alpha$-glucosidase activity was found in a muscle biopsy. In a second pregnancy in 1969 amniocentesis was performed but enzyme assays could only be performed on the amniotic fluid supernatant; a normal value was observed and fortunately a healthy girl was born (Table 3, II No 2). In the third pregnancy amniocentesis was carried out in the 15 th week but the mother came into spontaneous labor in the 19th week. A deficient acid $\alpha$-glucosidase activity was observed in various fetal tissues (II No 3 , Table 3 ). In the fourth pregnancy enzyme assays in cultured amniotic fluid cells were performed 17 days after amniocentesis (Table 2, II No 4). The activity was about half of the value in control amniotic fluid cells and about $30 \%$ of that in fibroblasts from the heterozygous mother. As the activity was about 10 -fold higher than that in fibroblasts from an affected sibling (Table 2) we decided that the fetus could be a carrier or normal. After the birth of a healthy girl enzyme analyses on leucocytes of umbilical cord blood showed a ratio of acid to neutral $\alpha$-glucosidase activity which was intermediate between the heterozygote and control range when maltose was used as a substrate (Table 3). With glycogen as substrate enzyme levels were found in the range of heterozygotes (22).

In family III Nie the first male child died at 6 months of shock and cardiopulmonary failure. Microscopic examination at autopsy showed vacuolization and glycogen accumulation in heart muscle fibers; no abnormalities were found in other organs. No biochemical studies were performed and a tentative diagnosis of Pompe's disease was made. The second child was a healthy girl. In the third pregnancy prenatal monitoring was requested. Amniocentesis was performed and the acid glucosidase activity in the cultured amniotic fluid cells (III Nie 3, Table 2) was comparable with that in a control sample and the fetus seemed not affected. The acid glucosidase activity in fibroblasts from both parents showed quite high values compared with most other values in obligate heterozygotes (Table 2). Later $\alpha$-glucosidase assays in the leucocytes of the parents were carried out using glycogen as substrate. Activities in the control range were observed which made it unlikely that the first affected sibling had died from Pompe's disease. Unfortunately, no cell material of the affected sibling was available for enzyme studies. If biochemical assays had been performed or cultured cells had been stored the amniocentesis could have been avoided. The third pregnancy resulted in a healthy girl who had a normal ratio of acid to neutral $\alpha$-glucosidase in her leucocytes using glycogen as substrate.

In family $I V V_{O}$ the first child died at the age of 3 months and the diagnosis of Pompe's disease was based on morphologic studies at autopsy. A second child was healthy. In the third pregnancy amniocentesis was carried out in the 14 th week but in vitro growth failed and enzyme assays could be performed only on the amniotic fluid supernatant. A normal value was found but the parents were informed about the limitations of this assay. They decided to continue the pregnancy, but an affected child (IVVO 3$)$ was born with cheilopalatoschizis, muscular hypotonia, cardi-

Table 1. Acid and neutral $\alpha-1,4$-glucosidase activities ${ }^{1}$ of various cell types in patients with glycogenosis II

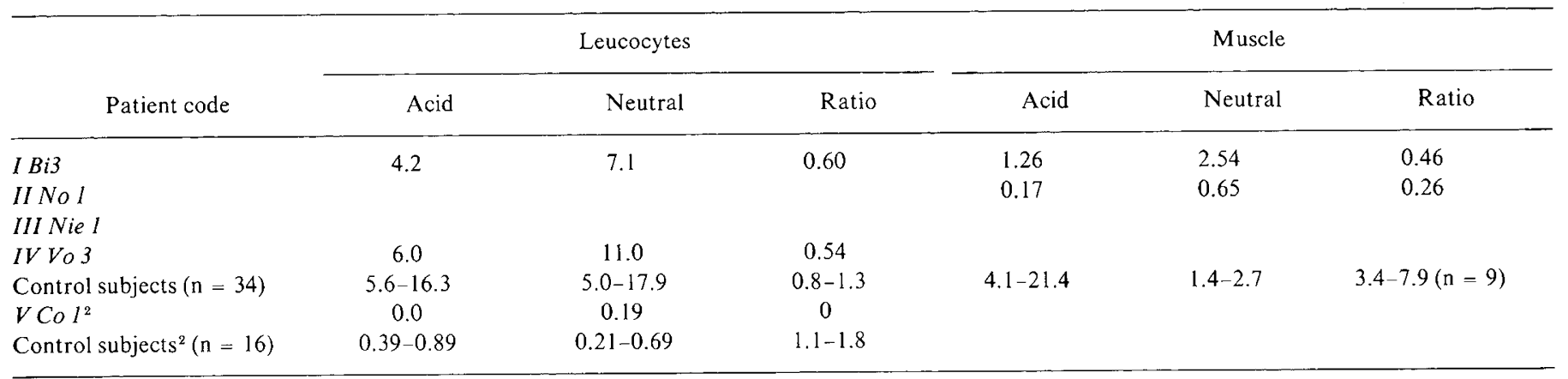

\footnotetext{
${ }^{1}$ Enzyme activities were measured with maltose as substrate at $\mathrm{pH} 4.0$ and 6.5 and expressed as in $10^{-9} \mathrm{~mol}$ glucose formed $/ \mathrm{min} / \mathrm{mg} \mathrm{protein}$.
}

${ }^{2}$ In these analyses enzyme activities were measured with glycogen as substrate at $\mathrm{pH} 4.0$ and 6.5 and expressed in the same units. 
Table 2. Prenatal diagnosis of Pompe's disease using homogenates of cultured amniotic fluid cells

\begin{tabular}{|c|c|c|c|c|c|}
\hline \multirow[b]{2}{*}{$\begin{array}{l}\text { Patient code and } \\
\text { cultivation period }\end{array}$} & \multicolumn{5}{|c|}{$\alpha$-1,4-Glucosidase activity ${ }^{1}\left(\times 10^{-12} \mathrm{~mol} / \mathrm{min} / \mathrm{mg}\right.$ protein $)$} \\
\hline & $\begin{array}{l}\text { Pregnancy } \\
\text { at risk }\end{array}$ & $\begin{array}{c}\text { Control } \\
\text { amniotic fluid } \\
\text { cells }^{3}\end{array}$ & $\begin{array}{c}\text { Control } \\
\text { fibroblasts }\end{array}$ & $\begin{array}{l}\text { Heterozygous } \\
\text { fibroblasts }\end{array}$ & $\begin{array}{l}\text { Pompe's } \\
\text { fibroblasts }\end{array}$ \\
\hline I Bi 4 (20 days) & 26 & 381 & $\begin{array}{l}2,760 \\
3,280\end{array}$ & $\begin{array}{ll}353 & q \\
480 & \delta^{3}\end{array}$ & 28 \\
\hline II No 4 (17 days) & 501 & 1,049 & 4,130 & $1,654 q$ & 59 \\
\hline III Nie 3 (22 days) & 680 & $\begin{array}{r}1,227 \\
715\end{array}$ & $\begin{array}{l}1,598 \\
5,326\end{array}$ & $\begin{aligned} 2,120 & \circ \\
822 & \delta^{3}\end{aligned}$ & 21 \\
\hline IV Vo 4 (14 days) & 112 & 614 & 1,010 & 475 \& & 27 \\
\hline$V$ Co 2 (12 days) & $104^{2}$ and $391^{*}$ & $261^{2}$ & & $372 \%$ & 25 \\
\hline
\end{tabular}

${ }^{1}$ Enzyme activity was determined with methylumbelliferyl substrate and in microvolumes.

${ }^{2}$ Analyses in primary cultures and $*$ after two subcultivations of the same cell strain.

${ }^{3}$ All control samples were later passages except for footnote 2 which was a primary culture.

Table 3. Confirmation of diagnosis after prenatal monitoring

\begin{tabular}{|c|c|c|c|c|c|}
\hline \multirow[b]{2}{*}{ Patient material } & \multicolumn{3}{|c|}{ Acid $\alpha$-1,4-glucosidase activity } & \multirow{2}{*}{$\begin{array}{l}\text { Ratio of acid to } \\
\text { neutral glucosidase } \\
\text { in leucocytes }\end{array}$} & \multirow{2}{*}{$\begin{array}{c}\text { Diagnosis in neonate } \\
\text { or in abortion } \\
\text { material }\end{array}$} \\
\hline & Musle & Heart & Liver & & \\
\hline$I \quad B i 4$ abortion & 1.2 & 0 & 0.4 & & M. Pompe \\
\hline II No 2 neonate & & & & 0.78 & Heterozygote or normal \\
\hline II No 3 abortion & 0.9 & & & & M. Pompe \\
\hline II No 4 neonate & & & & 0.93 & Heterozygote or normal \\
\hline IV Vo 4 abortion & 9.32 & 6.2 & 23.8 & & Heterozygote or normal \\
\hline$V$ Co 2 neonate & & & & 0.98 & Heterozygote or normal \\
\hline Control subject & $4.2-21.4(n=9)$ & & $21.7-38.8(n=4)$ & $0.8-1.3 \quad(\mathrm{n}=34)$ & \\
\hline Heterozygotes & & & & $0.63-0.97(\mathrm{n}=12)$ & \\
\hline M. Pompe & $0-1.6(n=16)$ & 0 & $0.1-0.5(n=3)$ & $0.25 \div 0.71(\mathrm{n}=11)$ & \\
\hline
\end{tabular}

${ }^{1} \alpha-1,4$-Glucosidase activities were assayed with maltose as the substrate at $\mathrm{pH} 4.0$ and $\mathrm{pH} 6.5$ and expressed as nmol glucose formed $/ \mathrm{min} / \mathrm{mg} \mathrm{protein}$.

omegaly, and a deficient acid $\alpha$-glucosidase activity in the leucocytes (Table 1). In the fourth pregnancy amniocentesis was performed in the 15th week and the results of enzyme assays on cultured amniotic fluid cells were available 2 weeks later (Table 2 , IV $V O 4)$. The acid $\alpha$-glucosidase activity was quite low compared with the control sample and with prenatal analyses performed earlier. The activity was about $25 \%$ of that of the fibroblasts from the heterozygous mother and about 4 times higher than in fibroblasts from the affected sibling. The fetus could have been a Pompe patient with a relatively high residual enzyme activity or a heterozygote with a very low activity. The parents were informed that the fetus was likely to be affected and the pregnancy was terminated at their request in the 17 th week. No deficiency of acid $\alpha$-glucosidase activity could be demonstrated in various fetal organs. We then speculated that the mistake in diagnosis was due to the fact that short term primary cultures of amniotic fluid cells from the pregnancy at risk had been compared with later passages from control amniotic fluid cell strains. The acid $\alpha$-glucosidase activities in various amniotic fluid cell samples were then measured at different periods of time in primary culture and were compared with the enzyme activities in subcultured cells at different intervals after the last subculture (Fig. 1). Acid $\alpha$-glucosidase activity showed no obvious correlation with time in culture, whereas the specific activity in subcultured cells showed a definite increase with time after subculture.

In the fifth pregnancy amniocentesis was performed and the

Fig. 1. Relation between acid $\alpha$-1,4-glucosidase activity and in vitro cultivation conditions of amniotic fluid cells. Different symbols represent cultures from different amniotic fluid samples. : cells from the same amniotic fluid sample at different time intervals in primary culture and after subcultivation.
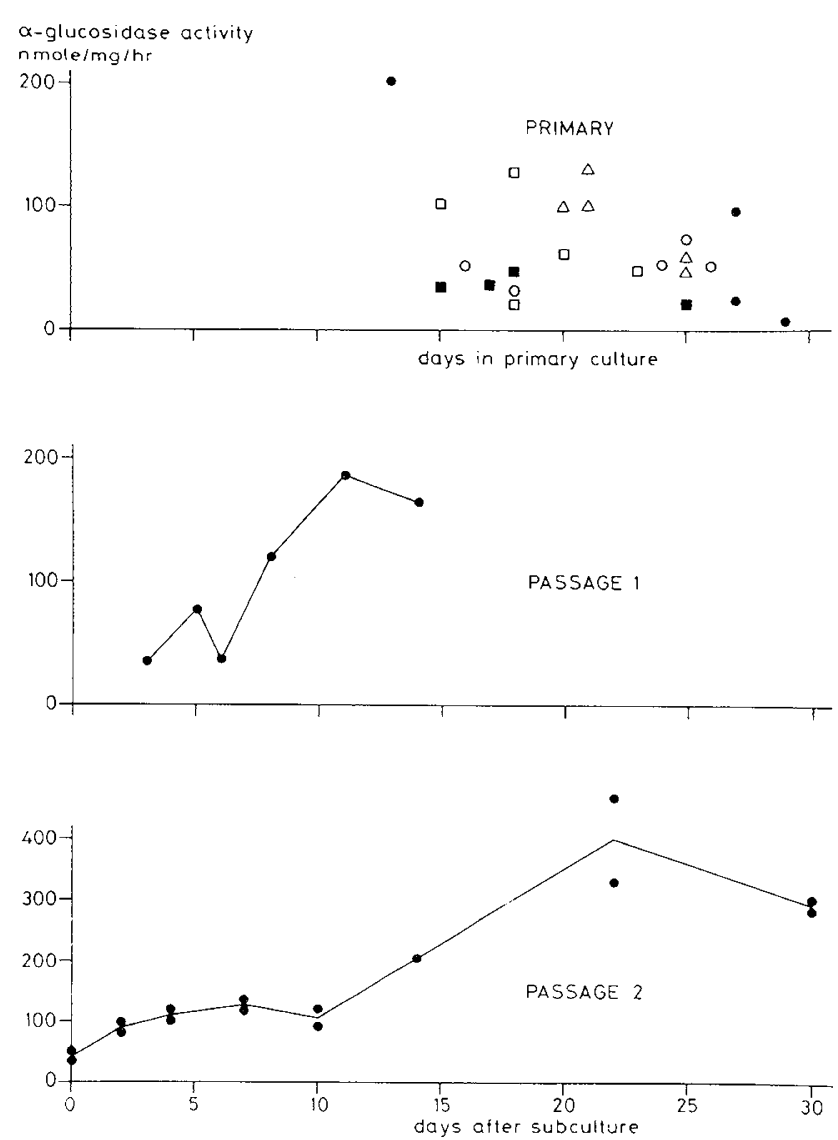
enzyme activity in a 12-day culture was compared with that of a primary culture of the same duration from a control sample. The acid $\alpha$-glucosidase activity in cells from the pregnancy at risk showed normal values and the pregnancy ended at term with the birth of a healthy child.

In family $V$ Co the first child died at 13 months of age with the classic symptoms of Pompe's disease. Biochemical assays on leucocytes revealed an acid $\alpha$-glucosidase deficiency (Table 1). In the second pregnancy enzyme assays on cultured amniotic fluid cells could be carried out 10 and 14 days after the second amniocentesis in the 17 th week. The results in Table 2 ( $V$ Co 2$)$ show that the acid $\alpha$-glucosidase activity in cells from the pregnancy at risk was $104 \mathrm{pmol} / \mathrm{min} / \mathrm{mg}$ protein, whereas a value of 391 was found in the second subculture of these cells. In control amniotic cells an activity of 261 was found at 21 days after initiation of a primary culture. From these results it was concluded that the fetus was not affected with Pompe's disease. The pregnancy was continued and a boy was born at term; the acid $\alpha$-glucosidase activity in his leucocytes was in the range between heterozygotes and control subjects with maltose as substrate (Table 3).

The results of these analyses indicate that for a reliable prenatal diagnosis, $\alpha$-glucosidase activities in short term (10-20 days) amniotic fluid cell cultures from pregnancies at risk should be compared with primary cultures of control amniotic fluid samples that have been grown under similar conditions.

\section{PRENATAL DIAGNOSIS USING MICROANALYSIS OF ISOLATED CELL GROUPS}

In the last three pregnancies at risk (III Nie 3, IV Vo 4, V Co 2), part of the amniotic fluid sample was used for microchemical analysis of isolated groups of freeze-dried cultured cells. This technique does not require parallel protein assays and harvesting can be carried out as soon as small cell clones appear. As a consequence prenatal diagnosis can be completed 10 - 14 days after amniocentesis during the 14 th -15 th week of pregnancy.

Table 4 shows the acid $\alpha$-1,4-glucosidase activities determined by this technique in 10 dissected groups of amniotic fluid cells from a pregnancy at risk (III Nie 3), in control amniotic fluid cells and in fibroblasts from a patient with Pompe's disease. The fluorescence intensities are well above the blank values for all groups of cells from the pregnancy at risk and the mean $\alpha$-glucosidase activity was found to be about half the value of that of control amniotic fluid cells. No acid $\alpha$-1,4-glucosidase activity was detected in dissected groups of fibroblasts from a patient with Pompe's disease. The data obtained indicated either a normal fetus or a heterozygous carrier. The mean glucosidase activity found in dissected cells from the pregnancy at risk are in good agreement with the enzymatic activity determined in cell homogenates from the same sample (Table 4 ).

To test the validity of microchemical enzyme analysis on dissected groups of cells, the results of such assays on various cell strains have been compared with data obtained by analysis on cell homogenates (Table 5). In the latter the enzyme activity is expressed as both per milligram of protein and per cell as calculated from the cell number of the sample before homogenization and from data on the protein content of single cultured cells $\left(2-3 \times 10^{-10} \mathrm{~g}\right)$ as determined by interference microscopy. These comparative studies indicate a good agreement between the results of the two methods for primary cultures of amniotic fluid cells and for later subcultures of normal amniotic fluid cells, fibroblasts from control subjects, patients with Pompe's disease, and heterozygous carriers.

\section{ANALYSIS OF $\alpha$-1,4-GLUCOSIDASE IN AMNIOTIC FLUID SUPERNATANT}

For five pregnancies at risk for Pompe's disease, where enzymatic analysis had been carried out on cultured amniotic fluid cells, the activities of acid and neutral $\alpha$-glucosidase have been determined in the amniotic fluid supernatant. The results in Table 6 show that there was no correlation between the acid glucosidase activity in amniotic fluid supernatant and the status of the fetus. Furthermore, it is apparent that the ratio of acid to neutral glucosidase was rather constant in all cases tested.

It is difficult, to conceive of a diagnostic approach which must be made under greater "blind" conditions: an opportunity does not exist to check the laboratory diagnosis with the physical examination and clinical course of the patient.

Kirkman, $1972(20)$

\section{DISCUSSION}

For the prenatal diagnosis of Pompe's disease three potential sources of diagnostic material have been proposed: uncultured

Table 5. Comparison of microanalysis of $\alpha-1,4$-glucosidase activity using dissected groups of freeze-dried cells and cell homogenates

Enzyme activity cell homogenate

\begin{tabular}{|c|c|c|c|}
\hline \multirow[b]{2}{*}{ Cell strain } & \multicolumn{3}{|c|}{ Enzyme activity cell homogenate } \\
\hline & $\begin{array}{l}\text { Dissected } \\
\text { cell groups }\end{array}$ & $\begin{array}{l}\text { per cell, } \\
\times 10^{-14} \\
\mathrm{~mol} / \mathrm{hr}\end{array}$ & $\begin{array}{c}\text { per } \mathrm{mg} \text {. } \\
\text { protein, } \\
\times 10^{-12} \\
\mathrm{~mol} / \mathrm{min}\end{array}$ \\
\hline \multicolumn{4}{|l|}{ Pregnancies at risk } \\
\hline III Nie 3 & 1.2 & 1.3 & 680 \\
\hline$I V V_{0} 4$ & 0.3 & 0.2 & 123 \\
\hline$V \operatorname{Co} 2^{2}$ & 0.4 & $0.2,0.8$ & $104,391^{2}$ \\
\hline \multicolumn{4}{|l|}{$\begin{array}{l}\text { Control amniotic fluid } \\
\text { cells }\end{array}$} \\
\hline Primary culture ${ }^{3}$ & 0.3 & 0.5 & $261^{3}$ \\
\hline $\begin{array}{l}\text { Later subcuitures } \\
\qquad(\mathrm{n}=2)\end{array}$ & $1.2,2.1$ & $1.1,1.5$ & 548,763 \\
\hline Control fibroblasts $(n=4)$ & $3.1 \cdots 5.1$ & $2.9-5.3$ & $1,440 \cdots 2,645$ \\
\hline Heterozygous fibroblasts & 1.5 & 1.0 & 500 \\
\hline Pompe's fibroblasts $(\mathrm{n}=3)$ & $\leq 0.3$ & $0.03-0.05$ & $18-26$ \\
\hline
\end{tabular}

${ }^{1}$ Data are the mean of values from 10-26 groups of cells.

${ }^{2}$ Freeze-dried cells have been analyzed after 10 days growth, but cell homogenate studies were performed after 14 days in primary culture and after the third subculture.

${ }^{3}$ Analysis of freeze-dried control cells after 14 days of primary culture; studies on cell homogenate after 21 days of primary culture.

Table 4. Microchemical analysis of $\alpha-1,4$-glucosidase in dissected groups of freeze-dried amniotic cells from a pregnancy at risk for Pompe's disease (III Nie 3)

\begin{tabular}{lrrrrrrrrrr}
\hline Number of dissected cells & 160 & 160 & 100 & 120 & 115 & 165 & 200 & 110 & 95 & 130 \\
Fluorescence intensity (relative units) & 11 & 12 & 9 & 15 & 12 & 12 & 20 & 10 & 9 & 10 \\
$\alpha$-1,4-Glucosidase activity $\left(\times 10^{-14} \mathrm{~mol} / \mathrm{hr} / \mathrm{cell}\right)$ & 1.0 & 1.0 & 1.1 & 1.8 & 1.4 & 1.0 & 1.5 & 1.2 & 1.0 & 1.0
\end{tabular}

Mean activity in pregnancy at risk: 1.2 (cell homogenate: $1.3 \times 10^{-14} \mathrm{~mol} / \mathrm{hr} / \mathrm{cell}$ )

Mean activity control amniotic fluid cells: 2.2

Mean activity fibroblasts Pompe: no detectable activity $\left(\leq 0.3 \times 10^{-14} \mathrm{~mol} / \mathrm{hr} / \mathrm{cell}\right)$

\footnotetext{
${ }^{1}$ Blank values of $3 \%$ (range 2-5\%) consisted of 10 empty pieces of plastic foil dissected adjacent to cell groups.
} 
Table 6. $\alpha-1,4-$ Glucosidase activities in amniotic fluid supernatant in pregnancies at risk for Pompe's disease

\begin{tabular}{|c|c|c|c|c|}
\hline \multirow{2}{*}{$\begin{array}{l}\text { Patient code } \\
\text { and time of } \\
\text { amniocentesis }\end{array}$} & \multicolumn{2}{|c|}{$\begin{array}{c}\alpha-1,4-G l u c o s i d a s e \\
\text { activity, }{ }^{1} \times 10^{-12} \\
\text { mol/min/mg. protein }\end{array}$} & \multirow{3}{*}{$\begin{array}{c}\begin{array}{c}\text { Ratio of } \\
\text { acid to } \\
\text { neutral }\end{array} \\
0.22\end{array}$} & \multirow{3}{*}{$\begin{array}{c}\begin{array}{c}\text { Outcome of } \\
\text { pregnancy }\end{array} \\
\text { Heterozygote }\end{array}$} \\
\hline & pH 4.0 & $\mathrm{pH} 6.5$ & & \\
\hline$I \quad B i \quad 4(14 \mathrm{wk})$ & 421 & 1,850 & & \\
\hline II No 4 (17 wk) & 759 & 3,498 & 0.21 & M. Pompe \\
\hline II No 4 (19 wk) & 216 & 1,059 & 0.20 & 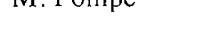 \\
\hline III Nie 4 (15 wk) & 196 & 823 & 0.23 & $\begin{array}{l}\text { Heterozygote or } \\
\text { normal }\end{array}$ \\
\hline$I V V_{O} \quad 3(15 \mathrm{wk})$ & 445 & 1,899 & 0.23 & Normal \\
\hline$V \operatorname{Co} 2(17 \mathrm{wk})$ & 359 & 1,465 & 0.24 & $\begin{array}{l}\text { Heterozygote or } \\
\text { normal }\end{array}$ \\
\hline Control (16wk) & 227 & 833 & 0.27 & Normal \\
\hline
\end{tabular}

${ }^{1}$ In all analyses methylumbelliferyl- $\alpha$-D-glucopyranoside was used as the substrate.

amniotic fluid cells (31), amniotic fluid supernatant (31), and cultured amniotic fluid cells $(6,30,31)$. At present it is clear that only cultured fetal cells permit reliable prenatal monitoring. The analysis of uncultured amniotic fluid cells is complicated by contamination with maternal white blood cells (6), the large proportion of dead cells which lose part of their enzymatic activity $(7,32)$, and contamination with enzymes which may be present in the amniotic fluid supernatant (41). The absence of acid $\alpha$ 1,4-glucosidase activity in the amniotic fluid supernatant was reported in a pregnancy of a fetus with Pompe's disease (31) but later studies $(30,37)$ could not substantiate a relation between the enzyme activity in the fluid supernatant and that in the fetal cells. The results in the present paper (Table 6) are in agreement with this last finding. Neither acid $\alpha-1,4$-glucosidase activity nor the ratio of acid to neutral glucosidase activity of the supernatant gave any conclusive information. This finding contradicts the assumption that acid $\alpha-1,4$-glucosidase activity in the supernatant is mainly derived from fetal cell organelles (38). Another suggested source for acid $\alpha$-1,4-glucosidase activity is an enzyme of renal origin with properties differing from the enzyme found in other tissues (37). The function of this enzyme and its rapid disappearance from the amniotic fluid supernatant after the 20th week of pregnancy $(9,42,43)$ needs further clarification. Since fetal urine contributes to amniotic fluid it is difficult to understand why Pompe's disease cannot be detected prenatally using amniotic fluid supernatant (9) if urine from patients can be used for enzymatic diagnosis after birth (39).

The only reliable material for prenatal diagnosis of Pompe's disease is cultured amniotic fluid cells. Our results (Table 2) showed that microchemical analysis of $\alpha$-glucosidase activity (13) in cell homogenates permits prenatal diagnosis 14-20 days after amniocentesis during the 15 th week of pregnancy. When microanalyses were carried out on small groups of dissected freezedried cells (Tables 4 and 5), a further reduction to 10-12 days was realized. Comparable procedures have been developed for the prenatal detection of a number of other lysosomal diseases $(11,12$, 14). The advantage of these micromethods is that a prenatal diagnosis can be completed before the mother experiences fetal movements and that multiple analyses including karyotyping can be performed on a small amount of cell material. In addition assays of other, nonaffected enzymes in the same culture can be performed to test enzyme preservation in the sample used.

Although the results of $\alpha$-1,4-glucosidase analyses on small groups of dissected freeze-dried cells correspond very well with assays on cell homogenates, the former method has some limitations if a conventional fluorometer is used. Groups of $100-300$ freeze-dried cells can be accurately analyzed with methylumbelliferyl substrates only if the enzyme activity is higher than $0.3-1 \times$
$10^{-14} \mathrm{~mol} / \mathrm{hr} / \mathrm{cell}$ (which corresponds to about $150 \mathrm{pmol} / \mathrm{min} / \mathrm{mg}$ protein). In order to distinguish cells from heterozygous carriers from cells from affected patients enzymatic activities higher than this level should be present. This is the case for enzymes with relatively high activities in cultured cells such as those involved in $\mathrm{GM}_{1}$ and $\mathrm{GM}_{2}$ gangliosidoses. In some instances of Fabry's disease (14) and Pompe's disease (see Table 5) the enzymatic activity in cells from heterozygous fetuses may be below the level of detection and erroneous interpretation is possible. Mistakes can be avoided either by microanalysis on cell homogenates in the case that more cell material is available or by the use of more sensitive microfluorometric methods $(12,13)$.

A prerequisite for prenatal monitoring should be that the diagnosis of the metabolic disease in the affected sibling is based on the demonstration of the enzyme defect in tissues or cultured cells. In two of the presently described cases such data were not available and the only possibility remaining is carrier detection in both parents. For this purpose the use of glycogen as substrate (22) has given the best results so far, although in larger series there is some overlap between control and heterozygote values.

For a reliable distinction between normal, heterozygous, and enzyme-deficient cells the use of appropriate controls is required. The residual activity of acid $\alpha$-glucosidase shows considerable variations in fibroblasts from different affected patients and in different heterozygous carriers (see Table 2). Part of this variation might be caused by differences in cell cultivation conditions (3-5, $8,23,35,36,40$ ), but also the residual enzyme activity may in part be genetically determined. Therefore, in prenatal diagnosis the enzymatic assays of cells from a pregnancy at risk should be compared with control amniotic fluid cells and with cultured fibroblasts from heterozygotes and an affected patient in that particular family. For this purpose parents of a child affected with a metabolic disease which can be detected in utero (29) should be informed in time about this possibility and skin biopsies should be taken so that cells can be stored until required for prenatal monitoring in a subsequent pregnancy.

Ideally, control amniotic fluid cell cultures should be from the same gestational period and grown for the same period of time as those from the pregnancy at risk. The use of later subcultures of control samples may lead to erroneous interpretations such as described for patient IV Vo 3 (see Table 2). The activity of acid $\alpha$-glucosidase (Fig. 1) and also of several other lysosomal enzymes is usually low in primary cultures and unpredictable variations have been observed at different time intervals after initiation of a primary culture. In this respect possible differences in enzyme activity between epithelioid and fibroblast-like amniotic fluid cells $(15,19)$ should be further investigated. In later subcultures of amniotic fluid cells the activity of acid $\alpha$-glucosidase increases during prolonged cultivation (2-3 weeks) after the last subculture. A similar effect has been reported by others and in fibroblasts the activity of several enzymes was found to increase considerably during growth in confluency $(3,4,8,35,40)$. The use of primary cultures of control amniotic fluid cells has been facilitated by methods for storing samples of uncultured amniotic fluid cells with maintenance of cell viability (33).

Of course, therapy of Pompe's disease by enzyme substitution would be preferable to preventive control by prenatal diagnosis followed by selective abortion, but preliminary results of therapeutic approaches $(1,17)$ warrant the conclusion that at present genetic counseling and prenatal diagnosis are the only practical means for prevention of this disease.

\section{SUMMARY}

1. In order to reduce the time interval between amniocentesis and prenatal diagnosis of Pompe's disease microchemical techniques were used for assay of acid $\alpha$-1,4-glucosidase activities in cultured amniotic fluid cells.

2. Microtechniques used on homogenates of cultured amniotic fluid cells enabled the waiting period to be reduced to $2-3$ weeks. 
3. When dissected lyophilized groups of 200-300 cultured cells were analyzed, a prenatal diagnosis was possible at about 10 days after amniocentesis.

4. The acid $\alpha-1,4$-glucosidase activity in the amniotic fluid supernatant is not informative in prenatal diagnosis of Pompe's disease.

5. Conditions of cell cultivation such as length of time in culture were found to influence markedly the acid $\alpha$-1,4-glucosidase activity in cultured amniotic fluid cells.

6. For a reliable prenatal diagnosis of metabolic disorders primary cultures of control amniotic fluid cells should be used and the analytical results from the pregnancy at risk should be compared with primary cultures of control amniotic fluid cells and with those in cultured fibroblasts from heterozygous carriers, and an affected sibling from the particular family.

\section{REFERENCES AND NOTES}

1. Barsy, T. de, Jaiquemin, P., Van Hoof, F., and Hers, H. G.: Enzyme replacement in Pompe's disease: An attempt with purified human acid $\alpha$-glucosidase. Birth Defects: Original Article Series, Vol. IX, No. 2, p. 184 (1973).

2. Brady, R. O., Uhlendorf, B. W., and Jacobson, C. B.: Fabry's disease: Antenatal detection. Science, 172: 174 (1971).

3. Butterworth, J., Sutherland, G. R., Broadhead, D. M., and Bain, A. D.: Lysosomal enzymes of cultured amniotic fluid cells. Clin. Chim. Acta, 44: 295 (1973).

4. Butterworth, J., Sutherland, G. R., Broadhead, D. M., and Bain, A. D. Lysosomal enzyme levels in human amniotic fluid cells in tissue culture. Life Sci., 13: 713 (1973).

5. Ceccarini, C., and Eagle, $\mathrm{H} .: \mathrm{pH}$ as a determinant of celluiar growth and contact inhibition. Proc. Nat. Acad. Sci. U.S.A., 68: 229 (1971)

6. Cox, R. P., Douglas, G., Hutzler, J., Lynfield, J., and Dancis, J.: In-utero detection of Pompe's disease. Lancet, $i$ : 893 (1970).

7. Davidson, R. G., and Rattazzi, M. C.: Prenatal diagnosis of genetic disorders Trials and tribulations. Clin. Chem., 18: 179 (1972).

8. DeMars, R.: Some studies of enzymes in cultivated human cells. Natl. Cancer Inst. Monogr., I3: 181 (1964).

9. Fluharty, A. L., Scott, M. L., Porter, M. T., Kihara, H., Wilson, M. G., and Towner, J. W.: Acid $\alpha$-glucosidase in amniotic fluid. Biochem. Med., 7: 39 (1973)

10. Fratantoni, J. C., Neufeld, E. F., Uhlendorf, B. W., and Jacobson, C. B.: Intrauterine diagnosis of the Hurler and Hunter syndromes. New Engl. J. Med., 280: 686 (1969)

11. Galjaard, H.: Techniques for rapid prenatal diagnosis of some inborn errors of metabolism (Abstract). Pediat. Res., 7: 56 (1973).

12. Galjaard, H., Hoogstraten, J. J. van, de Josselin de Jong, J. E., and Mulder, M. P.: Methodology of the quantitative cytochemical analysis of single or small numbers of cultured cells. Histochem. J., 6: 409 (1974).

13. Galjaard, H., Mekes, M., de Josselin de Jong, J., and Niermeijer, M. F.: A method for rapid prenatal diagnosis of glycogenosis II (Pompe's disease). Clin. Chim. Acta, 49: 361 (1973).

14. Galjaard, H., Niermeijer, M. F., Hahnemann, N., Mohr, J., and S $\phi$ rensen, S. A. An example of rapid prenatal diagnosis of Fabry's disease using microtechniques. Clin. Gen., 5: 368 (1974).

15. Gerbie, A. B., Melancon, S. B., Ryan, C., and Nadler, H. L.: Cultivated epithelial-like cells and fibroblasts from amniotic fluid: Their relationship to enzymatic and cytologic analysis. Amer. J. Obstet. Gynec., 114: 314 (1972).

16. Glick, D.: Quantitative Chemical Techniques in Histo- and Cytochemistry, Vols. I and II. (Interscience Publishing Co., New York, 1961, 1963).

17. Hug G., Schubert, W. K., and Soukup, S.: Treatment related observations in solid tissues, fibroblast cultures and amniotic fluid cells of type II glycogenosis. Hurler disease and metachromatic leucodystrophy. Birth Defects: Original Article Series, Vol. IX, No. 2, p. 160 (1973)

18. Huijing, F., van Creveld, S., and Losekoot, G.: Diagnosis of generalized glycogen storage disease (Pompe's disease). J. Pediat., 63: 984 (1963).

19. Kaback, M. M., Leonard, C. O., and Parmley, T. H.: Intrauterine diagnosis: Comparative enzymology of cells cultivated from maternal skin, fetal skin, and amniotic fluid cells. Pediat. Res., 5: 366 (1971)

20. Kirkman, H.,: Enzyme defects. Progr. Med. Genet., 8: 125 (1972).

21. Koster, J. F., Slee, R. G., and Hülsmann, W. C.: The use of leucocytes as an aid in the diagnosis of a variant of glycogen storage disease type II (Pompe's disease). Eur. J. Clin. Invest., 2: 467 (1972).

22. Koster, J. F., Slee, R. G., and Hülsmann, W. C.: The use of leucocytes as an aid in the diagnosis of glycogen storage disease type II (Pompe's disease). Clin.
Chim. Acta, 51: 319 (1974)

23. Lie, S. O., Schofield, B. H., Taylor, H. A., Jr., and Doty, S. B.: Structure and function of the lysosomes of human fibroblasts in culture: dependence on medium pH. Pediat. Res., 7: 13 (1973).

24. Littlefield, J. W.: Problems in the use of cultured amniotic fluid cells for biochemical diagnosis. Birth Defects: Original Article Series, Vol. VII, No. 5, p. 15 (1971).

25. Lowry, O. H.: The quantitative histochemistry of the brain: Histological sampling. J. Histochem. Cytochem., I: 420 (1953).

26. Lowry, O. H., and Passonneau, J. V.: A Flexible System of Enzymatic Analysis (Academic Press, New York, 1972).

27. Lowry, O. H., Rosebrough, N. J., Farr, A. L., and Randall, R. J.: Protein measurement with the Folin phenol reagent. J. Biol. Chem., 193: 265 (1951).

28. Matschinsky, F.: Quantitative histochemistry of glucose metabolism in the islets of Langerhans. In: U. C. Dubach and U. Schmidt: Recent advances in quantitative histo- and cytochemistry. (Hans Huber, Bern, 1971).

29. Milunsky, A., and Littlefield, J. W.: The prenatal diagnosis of inborn errors of metabolism. Ann. Rev. Med., 23: 57 (1972).

30. Nadler, H. L., Bigley, R. H., and Hug, G.: Prenatal detection of Pompe's disease. Lancet, ii: 369 (1970).

31. Nadler, H. L., and Messina, A. M.: In-utero detection of type-II glycogenosis (Pompe's disease). Lancet, ii: 1277 (1969).

32. Navon, R., and Padeh, B.: Prenatal diagnosis of Tay-Sachs genotypes. Brit. Med. J., 4: 17 (1971).

33. Niermeijer, M. F., Halley, D., Sachs, E., Tichelaar-Klepper, C., and Garver, K. L.: Transport and storage of amniotic fluid samples for prenatal diagnosis of metabolic diseases. Humangenetik, 20: 175 (1973).

34. Nitowsky, H. M., and Grunfeld, A.: Lysosomal $\alpha$-glucosidase in type II glycogenosis; activity in leucocytes and cell cultures in relation to genotype. $\mathbf{J}$. Lab. Clin. Med., 69: 472 (1967).

35. Okada, S., Veath, M. L., Leroy, J., and O'Brien, J. S.: Ganglioside GM2 storage disease: hexosaminidase deficiencies in cultured fibroblasts. Amer. J. Hum. Genet., 23: 55 (1971).

36. Ryan, C. A., Lee, S. Y., and Nadler, H. L.: Effect of culture conditions on enzyme activities in cultivated human fibroblasts. Exp. Cell Res., 71: 388 (1972).

37. Salafsky, I. S., and Nadler, H. L.: Alpha-1,4-glucosidase activity in Pompe's disease. J. Pediat., 79: 794 (1971).

38. Salafsky, I. S., and Nadler, H. L.: Intracellular organelles and enzymes in cell-free amniotic fluid. Amer. J. Obstet. Gynecol., I11: 1046 (1971).

39. Salafsky, I. S., and Nadler, H. L.: Deficiency of acid alpha glucosidase in the urine of patients with Pompe's disease. J. Pediat., 82: 294 (1973)

40. Shanfield, B., and Pinsky, L.: Effect of population density on the specific activity of various acid hydrolases in human skin fibroblast monolayers. Can. J. Genet. Cytol., 14: 871 (1972).

41. Sutcliffe, R. G., and Brock, D. J. H.: Enzymes in uncultured amniotic fluid cells Clin. Chim. Acta, 31: 363 (1971).

42. Sutcliffe, R. G., Brock, D. J. H., Robertson, J. G., Scrimgeour, J. B., and Monaghan, J. M.: Enzymes in amniotic fluid: A study of specific activity patterns during pregnancy. J. Obstet. Gynaec. Brit. Commonw., 79: 895 (1972)

43. Sutcliffe, R. G., and Brock, D. J. H.: Observations on the origin of amniotic fhuid enzymes. J. Obstet. Gynaec. Brit. Commonw., 79: 902 (1972).

44. Difco Laboratories, Detroit, Mich.

45. Flow Laboratories, Ayrshire, Scotland.

46. Falcon Plastics, Oxnard, Calif.

47. Melinex polyester film type 0, I.C.I., The Netherlands.

48. Amniotic fluids from control pregnancies were kindly șupplied by Dr. K. L. Garver, Department of Obstetrics and Gynecology, Magee's Woman's Hospital, Pittsburgh, Pa.

49. Koch-Light Laboratories, Colnbrook, Buckinghamshire, England.

50. Perkin-Elmer Fluorescence Spectrophotomer MPF-2A.

51. The authors thank these colleagues for permission to study their patients: Dr H. J. Huisjes, Department of Obstetrics and Gynecology, University Hospital, Groningen, Dr. C. H. Schreuder, Department of Pediatrics, Free University, Amsterdam, Dr. M. J. Kool, Department of Obstetrics and Gynecology, Free University, Amsterdam, and Dr. J. M. J. P. Gadiot, Apeldoorn, The Netherlands.

52. This study was financed in part by the "Preventie Fonds," The Hague, The Netherlands.

53. The authors thank for their expert technical assistance Mrs. C. Tichelaar-Klepper, Miss M. Mekes, and Miss R. G. Slee.

54. Requests for reprints should be addressed to: M. F. Niermeijer, M.D., Erasmus University, Department of Cell Biology and Genetics, P. O. Box 1738, Rotterdam, The Netherlands.

55. Accepted for publication January 10, 1975. 